\title{
Non-immune Hydrops Fetalis: Retrospective Evaluation of Pathophysiological Mechanisms
}

\author{
Non-İmmün Hidrops Fetalis: Patofizyolojik Mekanizmalarının Retrospektif Değerlendirilmesi
}

Sezin Unal, Dilek Ulubaş Işık, Nihal Demirel, Beyza Özcan, İstemi Han Çelik, Ahmet Yağmur Baş

Department of Neonatology, Etlik Zubeyde Hanım Women's Health Teaching and Research Hospital, Ankara, Turkey

\section{ABSTRACT}

Objective: Nonimmune hydrops fetalis (NIHF) is associated with abnormal fluid collections in fetal soft tissues and serous cavities due to nonimmunologic causes. It should be considered as a symptom, rather than a disorder. We aimed to investigate etiology and pathophysiology in cases with NIHF during a four-year time period.

Methods: Eleven live-born infants with NIHF were evaluated retrospectively. Demographic data, laboratory values, and results of specified tests were recorded. Etiology and pathophysiological mechanisms were established. Results: The mean gestational age at birth was $32.8 \pm 2.6$ weeks and the mean birth weight was $2545 \pm 809$ grams. All cases presented with edema and ascites. Chromosomal disorders (5/11) were the leading etiology. Pathophysiological mechanisms were observed as fetal hypotonia, fetal hypoxia, lymphatic disorders, hypoalbuminemia, early closure of ductus arteriosus, anemia, and right-sided heart failure. Mortality was $72 \%$.

Conclusion: In the presented study NIHF occurred as a symptom which was presented in various conditions based on different mechanisms. Evaluations made in infants with NIHF should aim both diagnosis of the condition as well as finding out the underlying pathophysiological mechanisms. Mortality rate in infants with NIHF is high even though the improvements in neonatal care.

Key Words: Hydrops Fetalis, non-immune, neonate, etiology, pathogenesis

\section{ÖZET}

Amaç: Non-immün hidrops fetalis (NIHF) fetal yumuşak doku ve seröz kavitelerinde anormal sıvı birikimi ile karakterlidir. Bu durum bir hastalık olarak değil bir bulgu olarak ele alınmalıdır. Bu çalışmada dört yıl süresinde ünitemizde izlenen NIHF olgularının tanılarını ve patofizyolojilerini incelemeyi amaçladık.

Hastalar ve Yöntem: 11 NIHF olgusu retrospektif olarak değerlendirildi. Demografik özellikleri, laboratuar testleri ve özellikli tanısal testlerin sonuçları kayıt edildi. Olguların tanıları ve NIHF oluşumuna yol açan patofizyolojik mekanizmaları tanımlandı.

Sonuçlar: Olguların ortalama doğum gebelik haftası $32.8 \pm 2.6$ hafta ve ortalama doğum ağırlığı $2545 \pm 809$ gram idi. Tüm olgularda ilk muayenede cilt ödemi ve asit bulgularının olduğu görüldü. Kromozomal hastalıklar (5/11) en sık tespit edilen tanı idi. Olgularda saptanan patofizyolojik mekanizmalar ise fetal hipotoni, fetal hipoksi, lenfatik hastalıklar, hipoalbuminemi, duktus arteriosusun erken kapanması, anemi ve sağ kalp yetmezliği olarak değerlendirildi. Mortalite $\% 72$ saptandı.

Sonuç: Bu çalışmada değerlendirilen olgularda NIHF birçok nedene bağlı olarak farklı mekanizmalar sonucunda ortaya çıkan bir bulgu olduğu görüldü. Dolayısı ile NIFH olgularında yapılan tanısal çalışmalar hem tanıyı hem de patofizyolojik mekanizmaları aydınlatmak üzere yapılmalıdır. Yenidoğan bakımındaki olumlu gelişmelere rağmen NIHF mortalitesi hala yüksek olan bir durumdur.

Anahtar Sözcükler: Hidrops fetalis, non-immün, yenidoğan, etiyoloji, patofizyoloji

Geliş Tarihi: 26.12.2016

Kabul Tarihi: 09.03.2017

Address for Correspondence / Yazışma Adresi: Sezin Unal, MD, Department of Neonatology, Etlik Zubeyde Hanım Women's Health Teaching and Research Hospital, Ankara, Turkey E-mail: sezinunal@gmail.com

CTelif Hakkı 2017 Gazi Üniversitesi Tıp Fakültesi - Makale metnine http://medicaljournal.gazi.edu.tr/ web adresinden ulaşılabilir. CC Copyright 2017 by Gazi University Medical Faculty - Available on-line at web site http://medicaljournal.gazi.edu.tr/

doi:http://dx.doi.org/10.12996/gmj.2017.29 


\section{INTRODUCTION}

Hydrops fetalis is a clinical condition characterized with abnormal fluid accumulation in fetal soft tissues and serous compartments. It is diagnosed with the occurrence of at least two of the following symptoms: skin edema (> $5 \mathrm{~mm}$ ), ascites, pleural effusion, and pericardial effusion. When hydrops fetalis develops due to causes other than immune factors, it is called as nonimmune hydrops fetalis (NIHF). NIHF accounts for $90 \%$ of all hydrops fetalis cases and its prevalence is in a range of $1 / 1500-1 / 3800$ neonates. Definitive diagnoses in NIHF, which is caused by maternal, placental, or fetal factors, can be made in $60 \%$ of the patients. Despite prenatal diagnosis and interventions, its mortality rate ranges between $60 \%$ and $90 \%$ (1).

NIHF can be considered in nine etiological categories: cardiovascular, placental, hematological, infectious, non-cardiac congenital, chromosomal, genetic, miscellanous, and idiopathic. The underlying pathophysiological mechanism is the liquid transportation imbalance between plasma and tissues. Four mechanisms explaining this condition have been claimed: elevated capillary hydrostatic pressure, decreased plasma osmotic pressure, lymphatic obstruction, and deterioration of peripheral capillary permeability (2). NIHF originates from one or more pathophysiological mechanisms caused by various etiologies, and it should be considered as a symptom, rather than a disorder. Epidemiological studies on NIHF mostly focused on the diagnosis of the patients, and underlying pathophysiological mechanisms have not been discussed. The aim of the present study was to examine underlying pathophysiological mechanisms in patients diagnosed with NIHF due to various etiologies.

\section{PATIENTS and METHODS}

The study was carried out retrospectively in Etlik Zübeyde Hanım Women's Health Training and Research Hospital after obtaining permission from the local ethics committee. Patients admitted to neonatal intensive care unit (NICU) between March 2012 and March 2016 reviewed. Cases diagnosed with NIHF by presence of at least two of the following symptoms: edema ( $\geq 5 \mathrm{~mm}$ ), pleural effusion, ascites, and pericardial effusion, were examined. Immunological causes were excluded by blood type/subgroup analysis and direct coombs tests. We recorded gestational age at birth, birth weight, gender, Apgar score, complete blood count, albumin $(\mathrm{mg} / \mathrm{dL})$, first capillary blood gas analyses $[\mathrm{pH}$, bicarbonate $(\mathrm{mmol} / \mathrm{L})$, base excess $(\mathrm{mmol} / \mathrm{L})]$, TORCH$\mathrm{S}$ serology, chromosome analysis, metabolic tests (tandem mass spectrometry, urine-serum amino acids, and urine organic acid examination), imaging tests (cranial and abdominal ultrasonography, echocardiography, and lung X-ray), as well as prenatal follow up features of the mothers (age, prenatal tests, and intrauterine interventions). Data about presence of pulmonary hypertension, mechanical ventilation, and inotrope and pulmonary vasodilatory treatment were also noted. Presence of pulmonary hypertension was established if there were $5 \%$ or more difference between preductal and postductal oxygen saturation and/or echocardiographraphic findings consisted of right to left atrial and/or ductal shunting and bowing to left or flattening of interventricular septum (3).

Collected data of cases were reviewed for pathophysiological mechanisms according to classification pointed in the literature as shown in Table $1(2,4)$.

Table 1. Mechanism, pathophysiology, and etiology in non-immune hydrops fetalis*

\begin{tabular}{|c|c|}
\hline Pathophysiologic Mechanisms & Etiology \\
\hline $\begin{array}{l}\text { Increase in hydrostatic capillary pressure } \\
\text { Excessive filtration of fluid into the interstitium }\end{array}$ & $\begin{array}{l}\text { Congestive heart failure due to heart disease, arrhythmia, vascular disorders, } \\
\text { anemia, renal disorders, and twinning } \\
\text { Elevated central venous pressure secondary to high intrathoracic pressure, vena } \\
\text { caval compression, heart failure } \\
\text { Chromosomal syndromes associated disturbed neurological function and secondary } \\
\text { hypotonia and decreased chest wall movements that increase the intrathoracic } \\
\text { pressure }\end{array}$ \\
\hline $\begin{array}{l}\text { Reduction of intravascular osmotic pressure } \\
\text { Decrease in fluid resorption by the vasculature }\end{array}$ & $\begin{array}{l}\text { Hypoalbuminemia due to hepatic dysfunction, capillary leak, nephrotic syndrome, } \\
\text { enteropathy, and chylothorax }\end{array}$ \\
\hline $\begin{array}{l}\text { Obstruction of lymphatic flow } \\
\text { Ineffective clearance of excess interstitial fluid }\end{array}$ & $\begin{array}{l}\text { Congenital lymphatic development malformation and compression by mass } \\
\text { Elevated central venous pressure due to high intrathoracic pressure, heart failure } \\
\text { Reduced lymph flow due to fetal hypomotility }\end{array}$ \\
\hline Damage to peripheral capillary integrity & Ischemia due to anemia, uteroplacental insufficiency \\
\hline Protein leak into interstitial spaces & Sepsis due to inflammatory mediators and endotoxins \\
\hline
\end{tabular}

*Adapted from references Bellini and Hennekam 2012, Randenberg 2010

\section{RESULTS}

Between March 2012 and March 2016, 62194 neonates were delivered and 7493 neonates were admitted to NICU. Eleven NIHF cases (1:5654 live birth) were diagnosed with NIHF, of which eight cases died (72\%). Eight cases were preterm, two cases were late preterm, and one was term. The mean gestational age at delivery was $32.8 \pm 2.6$ weeks and mean birth weight was $2545 \pm 809$ gr. Ten cases had prenatal NIHF diagnosis. Ten pregnancies were followed in our hospital but four of them refused prenatal diagnostic tests.
One pregnant women was referred prior to birth. Intrauterine thoracentesis was performed in two cases (case 7 and 9). All cases presented fetal distress symptoms and deteriorations in their biophysical profiles. Nine of the 11 patients were delivered by cesarean section. Ten cases were intubated in delivery room, thoracentesis and paracentesis were included in resuscitation in two cases. Demographic characteristics, primary diagnoses, etiology in pathophysiologic mechanism, and outcome of cases were shown in Table 2 . 
Table 2. Demographic characteristics, etiology, pathophysiology, and outcome of cases

\begin{tabular}{|c|c|c|c|c|c|c|c|c|c|}
\hline Case & Gender & GA & BW & Apgar & CPR & $\begin{array}{l}\text { Fluid } \\
\text { accumulation }\end{array}$ & Primary Diagnosis & $\begin{array}{l}\text { Etiology in } \\
\text { pathophysiological } \\
\text { mechanism }\end{array}$ & Outcome \\
\hline 1 & Male & 31 & 1220 & $3 / 5$ & ETT & $\begin{array}{l}\text { Skin - Ascites } \\
\text { Pericardial } \\
\text { effusion }\end{array}$ & Unidentified & Unidentified & $\begin{array}{l}\text { Died } \\
\text { (40 } 40^{\text {th }} \text { minute) }\end{array}$ \\
\hline 2 & Male & 33 & 2870 & $5 / 7$ & ETT & Skin - Ascites & Trisomy 21 & $\begin{array}{l}\text { Fetal hypotonia } \\
\text { Fetal hypoxia } \\
\text { Hypoalbuminemia }\end{array}$ & Alive \\
\hline 3 & Female & 29 & 1700 & $2 / 3$ & ETT & $\begin{array}{l}\text { Skin - Ascites } \\
\text { Pleural effusion }\end{array}$ & Trisomy 21 & $\begin{array}{l}\text { Premature closure } \\
\text { of ductus arteriosus }\end{array}$ & $\begin{array}{l}\text { Died } \\
\left.\text { (13 }^{\text {th }} \text { hour }\right)\end{array}$ \\
\hline 4 & Female & 35 & 3645 & $5 / 7$ & ETT & $\begin{array}{l}\text { Skin - Ascites } \\
\text { Pleural effusion }\end{array}$ & Unidentified & Unidentified & Alive \\
\hline 5 & Male & 31 & 3270 & $5 / 7$ & $\mathrm{ETT}+\mathrm{Tc} / \mathrm{Pc}$ & Skin - Ascites & Trisomy 21 & Lymphatic dysplasia & $\begin{array}{l}\text { Died } \\
\text { ( } 3^{\text {rd }} \text { month) }\end{array}$ \\
\hline 6 & Female & 38 & 3750 & $5 / 7$ & ETT & $\begin{array}{l}\text { Skin - Ascites } \\
\text { Pleural effusion }\end{array}$ & Unidentified & $\begin{array}{l}\text { Anemia } \\
\text { Hypoalbuminemia }\end{array}$ & $\begin{array}{l}\text { Ex } \\
\left(7^{\text {th }} \text { day }\right)\end{array}$ \\
\hline 7 & Female & 32 & 2310 & $4 / 7$ & $\mathrm{ETT}+\mathrm{Tc}$ & $\begin{array}{l}\text { Skin - Ascites } \\
\text { Pleural effusion }\end{array}$ & Unidentified & Unidentified & Alive \\
\hline 8 & Male & 32 & 2280 & $5 / 6$ & ETT & $\begin{array}{l}\text { Skin - Ascites } \\
\text { Pleural effusion }\end{array}$ & Trisomy 21 & Fetal hypotonia & $\begin{array}{l}\text { Died } \\
\text { (6 } 6^{\text {th }} \text { day) }\end{array}$ \\
\hline 9 & Male & 31 & 2200 & $5 / 7$ & ETT & $\begin{array}{l}\text { Skin - Ascites } \\
\text { Pleural effusion }\end{array}$ & $\begin{array}{l}\operatorname{der}(22) \quad t(17 ; 22) \\
(q 21 ; p 11) \\
\text { (subtel 17q+) }\end{array}$ & Fetal hypotonia & $\begin{array}{l}\text { Died } \\
\left(14^{\text {th }} \text { day }\right)\end{array}$ \\
\hline 10 & Male & 32 & 2875 & $6 / 6$ & ETT & $\begin{array}{l}\text { Skin - Ascites } \\
\text { Pleural effusion }\end{array}$ & Liver hemangioma & $\begin{array}{l}\text { Kasabach-Merrit } \\
\text { Syndrome } \\
\text { Anemia }\end{array}$ & $\begin{array}{l}\text { Died } \\
\left(5^{\text {th }} \text { day }\right)\end{array}$ \\
\hline 11 & Female & 36 & 1880 & $7 / 8$ & PPV & $\begin{array}{l}\text { Skin - Ascites } \\
\text { Pleural effusion } \\
\text { Pericardial }\end{array}$ & $\begin{array}{l}\text { Multiple congenital } \\
\text { anomalv }\end{array}$ & $\begin{array}{l}\text { Right ventricular } \\
\text { hypertrophy and }\end{array}$ & $\begin{array}{l}\text { Died } \\
\left.\text { ( } 4^{\text {th }} \text { hour }\right)\end{array}$ \\
\hline
\end{tabular}

GA: gestational age (weeks); BW: birth weight (grams); Apgar: 1 minute / 5 minute; CPR: cardiopulmonary resuscitation; ETT: endotracheal intubation; Tc: thoracentesis; Pc: paracentesis

We observed pleural effusion in seven cases and pericardial effusion in two cases while skin edema and ascites were present in all. The most frequent cause of NIHF in the study group was chromosomal disorders, which were observed in five patients. Trisomy 21 accounted for the $80 \%$ of cases with chromosomal disorders (4/11) and one patient had the chromosomal disorder of $\operatorname{der}(22) t(17 ; 22)(q 21 ; p 11)($ subtel $17 q+)$. The primary diagnoses of the other NIHF patients were liver hemangioma, multiple congenital anomaly, and anemia.

Imaging tests revealed pathologic features in two cases; Case 10: Abdominal computerized tomography; a heterogeneous-density hemangioma in the liver with a size of $65 \times 65 \times 65 \mathrm{~mm}$, showing peripheral nodular contrasting, and with irregular borders and lobulated contours and Case 11: Cranial ultrasound; corpus callosum agenesis.
Pathophysiological mechanisms were found to be hypoalbuminemia, anemia, lymphatic disorders, right heart failure due to early closure of ductus arteriosus, idiopathic right heart failure, fetal hypotonia, and fetal hypoxia. We could not define the primary diagnosis in four and pathophysiology in three cases. The metabolic tests and TORCH analyses were performed in all however none was diagnostic in any case. Laboratory tests of the cases and performed treatments are presented in Table 3. We performed paracentesis in five (5/11) and thoracentesis in six (6/7) cases. Ten cases required mechanical ventilation treatment, and four of which received surfactant treatment. Echocardiography was diagnostic in two cases; Case 3: premature closure of ductus arteriosus and Case 11: right ventricular hypertrophy. Pulmonary hypertension was observed in six cases (Case 1,3,4,6,8, and 11) that four of them required treatment. Four patients received albumin transfusion, three patients received thrombocyte transfusion, two patients received erythrocyte suspension, and one patient received fresh frozen plasma and cryoprecipitate. 
Treatments

Laboratory tests

\begin{tabular}{|c|c|c|c|c|c|c|c|c|c|c|c|}
\hline Case & $\mathrm{pH}$ & $\mathrm{HCO}_{3}$ & $\mathrm{BE}$ & Albumin & $\mathrm{Hb}$ & WBC & Platelet & Fluid drainage & $\begin{array}{l}\text { Mechanical } \\
\text { ventilation and } \\
\text { surfactant }\end{array}$ & $\begin{array}{l}\text { Inotrope/ } \\
\text { pulmonary } \\
\text { vasodilatory } \\
\text { treatment }\end{array}$ & $\begin{array}{l}\text { Blood product } \\
\text { transfusion }\end{array}$ \\
\hline 1 & $\mathrm{~N} / \mathrm{A}$ & $\mathrm{N} / \mathrm{A}$ & $\mathrm{N} / \mathrm{A}$ & $\mathrm{N} / \mathrm{A}$ & $\mathrm{N} / \mathrm{A}$ & $\mathrm{N} / \mathrm{A}$ & $\mathrm{N} / \mathrm{A}$ & None & SIMV & $+/+$ & - \\
\hline 2 & 6.96 & 21.2 & -14.6 & 1.9 & 13.3 & 26800 & 168000 & Paracentesis & SIMV *S & $-/-$ & $\begin{array}{l}\text { Albumin } \\
\text { TS }\end{array}$ \\
\hline 3 & 7.06 & 14.8 & -12.2 & 1.9 & 16.1 & 8660 & 93000 & Thoracentesis & $\begin{array}{l}\text { SIMV *S } \\
\text { HFOV }\end{array}$ & $+/+$ & Albumin \\
\hline 4 & 7.06 & 25.4 & -8.2 & 1.9 & 19 & 17870 & 152000 & Thoracentesis & SIMV *S & $+/+$ & Albumin \\
\hline 5 & 7.16 & 23.9 & -8.9 & 2.3 & 18.8 & 8430 & 236000 & Paracentesis & - & $-/-$ & - \\
\hline 6 & 7.27 & 22.6 & -5.0 & 1.2 & 8.9 & 77580 & 62000 & Paracentesis & SIMV & $+/-$ & $\begin{array}{l}\text { Albumin } \\
\text { ES, TS, TDP, } \\
\text { CP }\end{array}$ \\
\hline 7 & 7.23 & 21.4 & -4.3 & 2.5 & 16 & 11600 & 318000 & $\begin{array}{l}\text { Paracentesis } \\
\text { Thoracentesis }\end{array}$ & SIMV & $-/-$ & - \\
\hline 8 & 7.29 & 25.4 & -7.6 & 2.6 & 17.5 & 14320 & 233000 & Thoracentesis & $\begin{array}{l}\text { SIMV } \\
\text { HFOV }\end{array}$ & $+/+$ & - \\
\hline 9 & 7.15 & 16 & -9.8 & 2.5 & 18.6 & 27140 & 34000 & $\begin{array}{l}\text { Paracentesis } \\
\text { Thoracentesis }\end{array}$ & SIMV *S & $-/-$ & - \\
\hline 10 & 6.85 & 13.8 & -18.9 & 2.0 & 9.7 & 38690 & 50000 & None & SIMV & $-/-$ & ES, TS \\
\hline 11 & 7.05 & 10.1 & -18.3 & N/A & 16.1 & 8720 & 205000 & Thoracentesis & SIMV & $+/+$ & - \\
\hline
\end{tabular}

HCO3: mmol/L; BE: mmol/L; Albumin: mg/d; Hb: hemoglobin - gr/dL; WBC: /mm³; Platelet: /mm; CT: computerized tomography; USG: ultrasonography; HFOV: High frequency oscillatory ventilation; SIMV: synchronized intermittent mandatory ventilation; PHT: Pulmonary hypertension; ES: Erythrocyte suspension; TS: Thrombocyte suspension; FFP: Fresh frozen plasma, CP; cryoprecipitate

+ Tests were defined if pathologic

*S indicates the cases that were given surfactant

\section{DISCUSSION}

In our hospital, the prevalence of NIHF was found to be 1:5654 live births and 1:681 NICU admissions in the 4-year time period. In literature, there is a wide variation in prevalence of NIHF that ranges from $1 / 2500$ to $1 / 3800$ pregnancies. This difference is due to specialization of medical center, whether late pregnancy terminations were included, variations in definitions, and thoroughness in evaluation (5). Similarly, in our hospital, fetuses diagnosed with a congenital heart disease by fetal echocardiograph in the prenatal period are referred to appropriate health centers which leads to the low prevalence of NIHF cases than literature. Bellini and Hennekam reported in their meta-analysis that the most common cause is cardiovascular system anomalies $(20.1 \%)$, followed by hematological diseases $(9.3 \%)$, and chromosomal disorders (9\%) yet $18.2 \%$ of the patients could not be diagnosed (4). Antenatal referral of pregnancies with fetuses with heart diseases also affected the etiological classification of 11 NIHF cases included in the presented study, thus chromosomal disorders were found to be the most frequent diagnosis.

The real underlying mechanism of NIHF is the imbalance of liquid transportation between capillary and extravascular tissues, which occurs as a result of elevated capillary hydrostatic pressure, decreased plasma osmotic pressure, lymphatic obstruction, or deterioration of peripheral capillary permeability (2). Hence, NIHF may appear as a result of different pathophysiological mechanisms caused by similar etiologies as well as due to similar pathophysiologies caused by different etiologies. Therefore, NIHF needs to be considered as a symptom rather than a diagnosis.

In the literature, Trisomy 21 was reported as the second most frequent cause of chromosomal disorders to cause NIHF, and it was found in four out of five cases with chromosomal disorders. The main underlying mechanisms of NIHF caused by chromosomal disorders are the obstruction or poor development of the lymphatic system, heart failure due to congenital heart diseases or increase in central venous pressure due to fetal hypotoniahypomotility, decreased chest wall movements and rarely hypoalbuminemia $(2,4,6)$.
In the trisomy 21 cases we presented severe hypoalbuminemia and decreased fetal movements (Case 2), heart failure due to premature closer of ductus arteriosus (Case 3), poor development of the lymphatic system (Case $5)$, and fetal hypotonia (Case 8) were the identified pathophysiological mechanisms as described in the literature. Although premature closure of ductus arteriosus were attributed mostly to maternal salicylate use or intrauterine infections, Case 3 drew attention to its coexistence with trisomy 21 (7).

In case 9, peripheral chromosomal analysis showed derivation anomaly in Chromosome 22 - partial trisomy 17 (Mos46,XY,add(22).ish $\operatorname{der}(22)$ $\mathrm{t}(17 ; 22)(\mathrm{q} 21 ; \mathrm{p} 11)$ (subtel17q+)[6]/46,XY[94]). The derivative chromosome 22 (der 22) anomaly was previously reported to be associated with carcinoma of cervix and skin (8). This presented case is the first to document the association of der 22 anomaly with NIHF. In the patient, no other cardiac, infectious, or metabolic causes were detected thus fetal hypotonia-hypomotility was thought to be the cause of NIHF.

We observed anemia, the third most common cause of NIHF in the literature, in two cases. Case 6 was a preterm baby with hypoalbuminemia, thrombocytopenia, and disseminated intravascular coagulation in addition to anemia. After exclusion of thrombosis, infections, metabolic diseases, chromosomal disorders, leukemia, hemoglobinopathies, and cardiac anomalies, fetal hypoxia was thought to be the cause of both biochemical and clinical signs. However, we indentifed as rare pathology in Case 10 as the etiology of anemia; liver hemangioma. Co-existance of liver hemangioma, thrombocytopenia, and coagulopathy yielded the diagnosis of the KasabachMerritt Syndrome, the infrequent cause of $\operatorname{NIHF}(9,10)$. Hepatic hemangioma causes NIHF either due to heart failure caused by elevated arteriovenous shunt or as a result of anemia and the Kasabach-Merritt syndrome (11). In this patient, NIHF was considered to have developed as a joint impact of hypoalbuminemia, anemia, and fetal hypoxia. 
Case 11 had found to developed right ventricle hypertrophy and pulmonary hypertension in addition to corpus callosum agenesis and fetal distres. Besides the chromosomal analysis, metabolic tests and infection serology were normal. Right ventricle hypertrophy was reported to be associated with NIHF in the presence of antenatal closure of foramen ovale, fetal hypoxia, obstruction of right ventricle exit, or as idiopathic (12). Therefore that case was considered to have developed NIHF secondary to right heart failure which was triggered by fetal hypotonia and fetal hypoxia.

In studies carried out in Turkey, it was reported that $16 \%-35 \%$ of the NIHF patients could not get definitive diagnosis $(13,14)$. Similarly, we could not determine neither the etiology nor the pathophysiology of three out of 11 cases (26\%). That finding supported the the importance of autopsy as emphasized by Takçı et al to be diagnositic in half of the NIHF patients (13).

The frequency of liquid accumulation in serous compartments was reported to be ascites (85\%), pleural effusion (33\%), and pericardial effusion (22\%) (15). In the present study, skin edema occurred in all cases, ascites in 10 cases, pleural effusion in nine cases, and pericardial effusion in two cases as in line with the literature.

The 11 patients included in the present study needed various levels of respiratory (90\%), HFOV (19\%), surfactant treatment $(36 \%)$, and circulatory support (54\%) as well as blood and blood product transfusion (45\%). The ratios of supportive treatments were similar to literature as mechanical ventilation: 47-88\%, HFOV: $27-37 \%$, surfactant treatment: $29-43 \%$, blood and blood product transfusion: $60 \%(1,13,16)$.

What makes this study different than the other epidemiological studies is that the pathophysiological mechanisms along with primary diagnoses are discussed. Not being able to obtain permission for an autopsy, that specific placenta pathologies were not evaluated, and that the patients were not compliant to prenatal follow-ups were among the factors limiting our diagnostic approach.

Despite the developments in antenatal and neonatal intensive care, NIHF has high mortality. NIHF should be considered as a symptom rather than a disease, and during the assessment of the patients, not only etiologies, but also pathophysiological mechanisms should be evaluated, so treatment modalities could be managed accordingly.

\section{Conflict of interest}

No conflict of interest was declared by the authors.

\section{REFERENCES}

1. Abrams ME, Meredith KS, Kinnard P, Clark RH. Hydrops fetalis: a retrospective review of cases reported to a large national database and identification of risk factors associated with death. Pediatrics 2007; 120:84-9.

2. Randenberg $A L$ Nonimmune hydrops fetalis part I: etiology and pathophysiology. Neonatal Network 2010; 29:281-95.

3. Bendapudi $P$, Rao GG, Greenough A. Diagnosis and management of persistent pulmonary hypertension of the newborn. Paediatric Respiratory Reviews 2015; 16:157-61.

4. Bellini C, Hennekam RC. Non-immune hydrops fetalis: a short review of etiology and pathophysiology. American Journal of Medical Genetics 158a:597-605.

5. Murphy JH. 2004. Nonimmune Hydrops Fetalis. NeoReviews 2012 5:p5-p15

6. Karaboğa B, Gunes S, Bozgül A, Helvaci H, Orbatu D. Down Syndrome and Non-Immune Hydrops Fetalis: A Case Report of a Surviving Premature Infant. The Journal of Pediatric Research 2015; 2:230-2.

7. Wyatt-Ashmead J. 2011. Antenatal closure of the ductus arteriosus and hydrops fetalis. Pediatric and Developmental Pathology 14:469-74.

8. Atkin NB, Baker MC. Derivative chromosome, der(17;22)(q10;q10), in two carcinomas of the cervix uteri and one of the skin. Cance genetics and cytogenetics. 1994; 74:153-5.

9. Skopec LL, Lakatua DJ. Non-immune fetal hydrops with hepatic hemangioendothelioma and Kasabach-Merritt syndrome: a case report. Pediatric Pathology 1989; 9:87-93.

10. Anai T, Miyakawa I, Ohki H, Ogawa T. Hydrops fetalis caused by fetal Kasabach-Merritt syndrome. Acta Paediatrica Japonica 1992; 34:324-7.

11. Albano G, Pugliese A, Stabile M, Sirimarco F, Arsieri R. Hydrops foetalis caused by hepatic haemangioma. Acta Paediatrica 1998 87:1307-9.

12. Tomar $M$, Radhakrishnan $S$, Shrivastava S. Transient severe isolated right ventricular hypertrophy in neonates. Cardiology in the Young 2003; 13:384-6.

13. Takci S, Gharibzadeh $M$, Yurdakok M, Ozyuncu O, Korkmaz A, Akcoren Z, et al. Etiology and outcome of hydrops fetalis: report of 62 cases. Pediatrics and Neonatology 2014; 55:108-13.

14. Yiğit AK, Oguz SS, Dilmen U. Evaluation of Cases with Nonimmune Hydrops Fetalis. Turkish Journal of Pediatric Disease 2013; 1:1-5.

15. Mahony BS, Filly RA, Callen PW, Chinn DH, Golbus MS. Severe nonimmune hydrops fetalis: sonographic evaluation. Radiology 1984; 151:757-61.

16. Karadag N, Dilli D, Karagöl B, Dursun A, Kundak A, Hakan N et al. Hydrops Fetalis: A six years experience in a tertiary neonatal intensive care unit. New Medical Journal 2013; 30:181-186. 